\title{
Fiscal Evidence from the Nessana Papyri
}

\author{
Shaun O'Sullivan
}

In 1957, C.J. Kraemer published the non-literary papyri found in the 1930 s at the site of Nessana, about 70 kilometres south of Gaza. ${ }^{1}$ Leaving aside two hundred small fragments almost all datable to the late Roman period (500-630), there are eighty-four larger documents from late Roman and early Islamic periods. Thus, forty-nine of these papyri are datable from 505 to about 630 . They include legal contracts, accounts, private letters and one fiscal register. The remaining thirty-five documents are datable from 674 to about 690 . They include fourteen non-fiscal documents - namely, two legal papers, ten private accounts and two official accounts listing Arab soldiers, their assignments and annual pay.

The remaining twenty-one papyri from the period 674-69o are fiscal documents. They include nine official demand-notes known as entagia, standardised documents requiring payment of money and foodstuffs, written in Arabic with a Greek translation below. Two other special demand notes require the provision of guides and porters. The fiscal documents also include eight official tax receipts and local tax accounts. Two unusual documents, finally, are a register listing all adult male payers of poll-tax in Nessana and a letter sent to Nessana from an unidentified nearby town. This letter informs of a planned protest against high taxes, to be made by representatives from all the local towns before the Arab governor in Gaza.

Almost the whole Nessana collection was found in a small room next to the church and monastery of St Sergius. The clerics of St Sergius were among the leading people in Nessana, and they came from a single family, following one another successively from at least $55^{\circ}$ until 690 and probably until Nessana ceased to exist at some point during the early eighth century. The papers had been deposited without arrangement in what was likely a church store-room for miscellaneous documents.

It is known that churchmen did not enjoy fiscal exemptions in the Christian Empire and thus paid the ordinary taxes. But the forty-nine late Roman papyri from Nessana include only one fiscal document, which suggests that the

1 Kraemer, Excavations.

(C) SHAUN O'SUlLIVAN, 2015 | DOI:10.1163/9789004284340_006

This is an open access chapter distributed under the terms of the prevailing CC-BY-NC License at the time of publication. 
churchmen at Nessana during the Late Roman period were not concerned to preserve fiscal papers. This may be explained by a law of the emperor Marcian (r. 450-457) decreeing that a tax-payer who could produce receipts for three consecutive years would be deemed to have paid all previous taxes. ${ }^{2}$ In contrast, the thirty-five papyri from the period 674-69o include twenty-one various fiscal documents, which suggests that churchmen in this later period were concerned to preserve fiscal papers for a much longer period. A similar contrast exists between papyri of the late Roman and Umayyad periods found at Qāw al-Kabīr/Antaeopolis and Ishqūh/Aphrodito in Egypt.

The question arises why tax-payers in early Umayyad Palestine and Egypt took care to preserve fiscal papers such as demand notes and receipts. Most likely, they were obliged to deal with burdensome tax authorities that continually required proof of payment. The fact that the church of St Sergius kept many fiscal papers during the period $674-690$ is circumstantial evidence that an exacting fiscal climate existed at Nessana. This suggests that the Umayyad administration not only produced much administrative documentation but also required tax-payers to present and reproduce documentation proving that they had fulfilled their fiscal dues. Evidence of such close administrative scrutiny of tax-payers and tax-payments also exists for Umayyad Egypt. ${ }^{3}$

The wider question of Late Roman and Umayyad taxation rates in the Near East will not be settled until new material evidence is published, probably from the numerous papyri stored in European libraries. But evidence already published allows the construction of four models of local economies that may have wider significance. Two of the four models represent the economy of Nessana in the mid-sixth century and the late seventh century, and the other two models represent the district of Antaeopolis in Lower Egypt during the same periods. The models include a set of constant factors, given below, and they rest on three basic assumptions.

The first assumption is that Nessana and Antaeopolis throughout the period $55^{0-700}$ had agrarian economies based on grain production, in which the grain fed cultivators and their dependents, $80-90 \%$ of the total population, and the surplus was converted into all other activity through exchange, rents and taxes. The importance of grain production becomes apparent when the agrarian economy is considered over the long term. Grain sustains the human and animal labour required for all productive activity such as growing olives and

2 Jones, The decline.

3 Sijpesteijn, The Arab conquest. 
vines, herding cattle, felling timber, mining metals, manufacturing pottery and textiles, building houses and ships, transporting goods, undertaking administrative and domestic services, and raising children. The economic value of all such non-grain production equals the grain consumption required for its realisation (consumption of water and air is not given economic value). This quantity of grain is the surplus remaining after the needs of the grain-producers have been satisfied. Over the longer term, the economy's grain production becomes equivalent to total production. That is, all capital existing at any moment equals the accumulated value of grain produced over previous decades and centuries. Ultimately, the agrarian economy is the actualisation of grain, a concept grasped by Vico in the eighteenth century. He theorised that grain was the only means of exchange and standard of value in the most primitive societies. Gold was later substituted for grain, not because it was deemed to be intrinsically precious but because it best represented grain by its colour of bright yellow. 4

The second assumption, well supported by archaeological evidence, is that cultivated land area had reached its Late Roman maximum by the early sixth century in Egypt and Palestine. In consequence, grain production and population were also at their peak during this period. But all these factors diminished owing to the plague that first appeared in 541 and returned several times before the Arab conquest. The plague significantly reduced the population of Egypt and Palestine. ${ }^{5}$ If it were as virulent as the medieval Black Death, which it closely resembled according to contemporary accounts, then the population of Egypt and Palestine may have fallen by one-third between 541 and the Arab conquest. However, cultivated land area and grain production in Egypt and Palestine probably fell by a lower proportion. As the economic models show, the agrarian economy is elastic. The same level of grain production can be maintained by a smaller labour-force if each cultivator works longer. The result is a larger grain surplus that may be converted into higher taxes, higher rents, or higher consumption by the cultivators, depending upon the prevailing relationship between the State, landowners and grain-producers. The Roman State and its dominant landowning class rested upon the taxes and rents provided by the cultivators. When the plague reduced the grain-cultivating population by as much as one-third, the State and the landowners were concerned to maintain cultivated land area and grain production as much as possible. ${ }^{6}$ The heavier

4 Vico, New science 539-547.

5 Sarris, The Justianic plague; Sarris, Procopius 217-219; Horden, Mediterranean plague.

6 For the effects of the plague on the economy, see Banaji, Agrarian change, Banaji, Aristocra- 
work-load necessarily placed upon the surviving grain-producers was probably offset by their keeping a larger share of the surplus. In other words, there was an effort to distribute equitably the economic burden imposed upon society by the plague. Hence peasant unrest is not recorded in Egypt and Syria during the period 541-630, and archaeological work reveals that the best quality of stone housing and church mosaics in villages of Roman Syria is datable to the sixth century. ${ }^{7}$

The third assumption is identical to the Malthusian law. In the agrarian economy, the rural cultivators and dependents $(80-90 \%$ of total population) live slightly above subsistence level. Under normal circumstances, the cultivating population tends neither to decline nor to remain constant, but to increase. As stated above, the elasticity of the agrarian economy permits a reduced population to maintain grain production if each cultivator works longer. Likewise, if the population grows and the amount of grain produced remains the same, then the work-load of each cultivator will diminish. A larger population thus brings each member the benefit of an easier physical existence. Conversely, there is normally little interest for the cultivators in having few children and in working longer with the aim of maximizing grain-production. The conditions of agrarian life are simple and unchanging. Only so much food can be consumed, and the close-knit society discourages the individual display of wealth. Cultivators have little opportunity to invest a larger grain surplus except through land purchase. Unless extracted through higher taxes and rents, a larger surplus is likely to be amortised in church treasures or coin hoards, of which examples dating to the Late Roman and Umayyad periods have been unearthed in Syria.

The agrarian population tends to reach the highest number that can be supported by net product, defined as total grain production minus 1) the amount that must be stored for the next year's seed, and 2) amounts extracted in outward-going rents (i.e. rents to landlords living outside the agrarian zone, in cities or abroad) and in taxes to the State. Rents paid to landlords living inside the agrarian zone are insignificant in Syria because most landlords live in cities. An insignificant quantity of grain is also subtracted from total grain production through spoilage. Outward-going rents and taxes together supply all the needs of the urban population, which constitutes $10-20 \%$ of the total population and includes the State apparatus of army and civil service. Most city-dwellers live on

cies and Sarris, The Justianic plague, Sarris, Rehabilitating the great estate and Sarris, Economy and society. For measures taken by the Roman government to compensate for a loss of fiscal revenue due to the plague, see also Ruffini, Social networks 146.

7 Foss, Syria in transition 199-202. 
small salaries that purchase little more than their needs in food, fuel and rent. Rents and taxes tend to compete with each other for the grain surplus. When one rises or falls, the other is likely to be affected, but in this period rents paid to landowners were relatively inflexible because they were traditionally a fixed proportion of the crop. In Late Roman Palestine and Egypt, the landowning class was numerous and powerful, but it enjoyed little margin for rent increase in the face of State fiscal requirements on the one side and a free sharecropping peasantry on the other. The margin was further reduced in the later sixth century when plague losses threatened to reduce grain production. With the Arab conquest, the class of city-dwelling large landowners was largely eliminated in Palestine and Egypt. Many took flight to the Empire's remaining territory. Many of those who remained served in the administration of the conquerors, but their former rents were now redirected as tax, for the grain surplus was monopolised by the Islamic State. ${ }^{8}$

If rents were fixed in the decades before the Arab conquest and insignificant afterwards, the important variable in the models for both periods is the tax. It may now be asked what happens to the agrarian economy of these models if the tax rises significantly and permanently. Total grain production (total product) remains the same, but the other factors change. The higher tax reduces net product (total product minus seed, rent and tax). In order to remain collectively above subsistence level, the population must fall correspondingly, which means that over the next generation more aged people and infants will die and fewer children will be raised. Higher tax and lower population result in higher tax per capita. But since total product is unchanged, higher tax per capita is offset by a higher share of total product per capita. In the agrarian economy as seen over several decades, the real burden of higher tax does not lie in the payment of more money per tax-payer (though individual tax-payers would often feel the burden as such) but in the fact that the reduced number of cultivators must work more days in order to achieve the same total product. Like the stretching of an elastic band, the tax may continue to rise and the population may continue to fall without affecting total product, up to the point where the cultivators are working at full capacity. This would be 365 days per year in theory, but in practice it would be considerably less in order to allow for sickness, injury and other incapacitating

8 For the position of Egyptian land-owners in post-conquest Egypt, see Sijpesteijn, Landholding patterns. See also Frantz-Murphy, The economics of state and in $C P R$ XXI on the significance of the Umayyad condition of maintaining that all conquered land was collectively owned by the Muslim community. 
factors. But once the tax rises above a certain maximum and net product correspondingly falls below a certain minimum, then the cultivators will become too few to achieve the total product even when they are working at full capacity. From that point, total product must fall, and the tax must fall with it. In practice, it seems unlikely that the cultivating population could bear the theoretical maximum fiscal burden for long. Around the point of maximum exploitation, the elastic band would snap. Grain production and tax payments would collapse together as cultivators abandon their lands and take flight.

Constant factors for the models are now introduced (Appendix A). Grain production is measured by the Roman modius, which has a capacity of 9 litres and holds 6.55 kilograms of grain. ${ }^{9}$ An average person living at subsistence would consume about 40 such grain-units per year, equivalent to just over 26o kilograms of grain. ${ }^{10}$ About two-thirds of the grain-units (26-27 units, 175 kilograms) are directly consumed at the rate of half a kilogram per day as bread and other grain-based food. About 6.5-7 units (45 kilograms) are converted through exchange into other foods (oil, dairy-products, honey, fruit, vegetables and wine) in order to reach a daily intake of at least 2,00o calories. The remaining 6.5-7 units (45 kilograms) are converted into fuel (mainly firewood), clothing and miscellaneous items. Food and drink thus account for over four-fifths of annual consumption and other necessities for less than onefifth.

The gold solidus or dīnār was used for paying taxes and salaries. Although its purchasing power in the market varied greatly depending on local circumstances, the solidus had a nominal fixed value of 33 grain-units in the late Roman period and 30 units in the Umayyad period. ${ }^{11}$ An annual net income of around five solidi would just support a household of four persons, but citydwellers needed somewhat more in order to meet the cost of rent and higher prices. $^{12}$

Constant factors are also available for the productivity of grain-land. In the ancient world, ordinary grain-land yielded on average between seven-fold and eight-fold, such that twenty units are usually sown per hectare $\left(10,000 \mathrm{~m}^{2}\right)$ to yield 150 units. However, only half of ordinary land is cultivated each year, the other half lying fallow to recuperate. Irrigated Egyptian land, on the other hand,

\footnotetext{
$9 \quad$ Jones, The decline 376.

10 Hopkins, Taxes and trade.

11 Jones, The decline 179.

12 Jones, The decline 290.
} 
normally yields ten-fold and it does not require a fallow period. However, fewer grain-units, usually only twelve units per hectare, are sown to yield 120 units on Egyptian land. One-eighth of the annual yield on ordinary land must be set aside for next year's seed; and one-tenth of the yield on Egyptian land must be set aside. ${ }^{13}$

Finally, constant factors are given for labour. The first-century author Columella states that one hectare of ordinary grain-land requires about 60 mandays for efficient cultivation..$^{14}$ In other words, one labour-unit, equivalent to one adult male aged between fourteen and sixty, can cultivate six hectares per year working at theoretical full capacity of 360 days per year. This factor may be taken as roughly true for irrigated Egyptian land also, although its cultivation probably required more than 60 man-days per hectare because of the need to maintain irrigation works. Finally, the labour-units available for grain cultivation are assumed normally to be adult males. With women and children thus excluded, the labour-units would equal about one-third of the total cultivating population. The proportion would increase to one-half if the labour of women and children were added, a woman being counted as half a labour-unit and a child as one-quarter of a unit.

\section{Model I: Antaeopolis ca. 550 (Appendix B)}

For Antaeopolis at this time the papyri give key statistics for the total tax of the district and its cultivated area. Of the total tax, $62 \%$ is paid in gold solidi and $38 \%$ in grain-units. With units converted into gold, the total tax comes to 16,500 solidi. The cultivated area is 14,000 hectares $\left(140 \mathrm{~km}^{2}\right)$, about $0.5 \%$ of all cultivated land in Egypt. ${ }^{15}$ Using the factors for productivity and labour, it can be deduced that this area would yield a total product of 1,700,00o grain-units requiring 840,000 man-days for cultivation. The total product is equivalent to 51,000 solidi at the standard rate of 33 units per solidus. The tax-rate is therefore $32.5 \%$, and another $10 \%$ for seed must be deducted from total product.

However, the evidence for Antaeopolis ca. $55^{\circ}$ does not indicate how much is deducted from total product by way of outward rents. Supposing at a guess that deduction for rents amounts to another $7.5 \%$ of total product, then net product is $50 \%$ of total product, 850,000 grain-units. This amount would support 21,000

\footnotetext{
13 Jones, The decline 300; Kraemer, Excavations 237-240.

14 Jones, Census records 49-64.

15 Jones, The decline 179.
} 
people, of whom one-third, 7,00o, are adult males engaged in cultivation. From each of these labour-units, 120 days of work per year would be required to meet the necessary 840,000 man-days. Finally, with the population of 21,000 grouped into just over 5,000 households of four persons each, the annual tax paid by each household reaches 3.1 solidi.

The model can be checked by extension to the whole country since we know that the Antaeopolis district covered about $0.5 \%$ of Egyptian cultivated land. The result would be an Egyptian population of 4.2 million people excluding Alexandria, which probably had a population of 300,000 at that time. The total of 4.5 million people lies within the accepted range for Egypt in the Late Roman period, but it might be somewhat high considering that the model reflects the agrarian economy not long after the outbreak of the plague in $541 .^{16}$ The deduction of $7.5 \%$ for rent is probably too low. If rent deductions are raised to $16 \%$, equal to half of the tax, then net product falls from $50 \%$ to $42 \%$, yielding 714,000 grain-units supporting 18,000 people. Labour-units work 140 days per year, and tax per household rises to 3.7 solidi. The population of Egypt would then reach 3.9 million including Alexandria. Lying in the middle of the accepted range, this figure seems quite plausible.

\section{Model II: Nessana ca. $55^{\circ}$ (Appendix c)}

The second model represents Nessana in the same period of the mid-sixth century, probably some time after the first outbreak of plague in 541. There are two pieces of papyri evidence for this period. ${ }^{17}$ Papyrus no. 82, a list of grain yields, confirms that Nessana's ordinary grain-land yields sevenfold to eightfold, a remarkable achievement for such an arid region. Papyrus no. 39 gives Nessana's tax in gold at that time as just over 1400 solidi. We now make the assumption that Nessana paid taxes in gold and grain in roughly the same proportion as was paid by Antaeopolis during the same period, namely 62:38. In that case, the total tax paid by Nessana is equivalent to 2,250 solidi. There is no certainty here, but we know that Late Roman taxes were levied in gold and in kind, and we can assume that during this period of plentiful gold coinage, the proportion of the tax paid in gold was normally higher than the proportion paid in grain. Therefore, the Antaeopolis ratio of 62:38 seems a reasonable standard to apply elsewhere.

\footnotetext{
16 Allen, Justinian plague $5^{-20 .}$

17 Kraemer, Excavations 119-125, 237-240.
} 
In the model for Antaeopolis, net product was at first taken to be $50 \%$ of total product after deductions of $32.5 \%$ in tax, $10 \%$ in seed and $7.5 \%$ in rent. Alternatively, rent was increased to $16 \%$, which reduced net product to $42 \%$. The second alternative gave a population figure that seemed more likely when extrapolated for all Egypt ca. 550. Let us follow the same procedure for Nessana ca. 550 , assuming at first that rent is $7.5 \%$ of total product and that net product is $50 \%$. In the case of Nessana's ordinary grain-land, seed deductions are $12.5 \%$ instead of $10 \%$ as at Antaeopolis, so the tax rate should be reduced from $32.5 \%$ to $30 \%$ in order to keep net product at $50 \%$. The other factors are calculated as follows. Total product is 248,000 grain-units, equivalent to 7,530 solidi. Total cultivated area is 3,100 hectares, of which only half is cultivated each year. The population is 3,100, with 100 days of labour required from each cultivator, and the tax per head of household is 2.9 solidi. As a check, the estimate of 3,100 people gives a density of 260 persons per hectare in the town's built-up area of 12 hectares. This seems high compared to the widely accepted yardstick of 200 persons per hectare for ancient Near Eastern settlements. $^{18}$

Supposing now that rent in this model is $16 \%$ of total product, then net product falls to $42 \%$, which would yield 104,000 grain-units supporting 2,600 people. Labour-units would work 115 days per year and tax per household would rise to 3.5 solidi. Population density would fall to 190 persons per hectare, which seems more likely for a straggling, unwalled settlement such as Nessana.

\section{Model III: Antaeopolis ca. 700 (Appendix D)}

The third model represents Antaeopolis at the start of the eighth century. There is no fiscal information for this period from Antaeopolis itself, but Umayyadperiod fiscal papyri have been found at the site of Aphrodito, a district lying adjacent to Antaeopolis in the same part of Upper Egypt. Analysis of this documentation shows that the Umayyad tax was paid like the Roman tax, in both gold and foodstuffs. But the single Roman tax in gold was now divided into two separate taxes known in the Aphrodito papyri as diagraphon and demōsia. Diagraphon was assessed on land and payable by all landowners, whereas demōsia was assessed on all adult males. In most cases, however, landowners were adult males, the main exception being widows who had inherited their deceased husbands' estates. Likewise, each adult male was usually a household head. In 
practice, then, the same people usually paid both diagraphon and demōsia, and relatively few paid only one of these taxes.

The best piece of fiscal evidence from Aphrodito is P.Lond. IV 1420, a document listing tax payments in the village of Pente Pediades (Five Fields) for the year 705. The village contained 95 adult males whose demōsia averaged 2.4 solidi each. The total diagraphon paid by the village in 705 is also listed, and if we assume that this tax was paid by 95 people, then each paid on average 2.3 solidi. In addition, P.Lond. IV 1420 records that the village made regular payments of grain and oil during the same year. The grain is calculated in Roman modii (mudd) and the oil in sextarii (qist), one sextarius being equal in value to one modius. Converting these foodstuffs into gold-equivalent at the rate of 30 grain-units per Umayyad solidus, and then dividing the result by the known number of adult males in the village, we find that each tax-payer paid on average the equivalent of 2.1 solidi in foodstuffs. The combined total tax per household for the village of Five Fields in the Aphrodito district in the year 705 can thus be estimated at 6.8 Umayyad solidi. ${ }^{19}$

It is assumed that this total figure can be applied to Antaeopolis. But we make the prior assumption that rent payments to city-dwelling landlords in Umayyad Egypt ca. 700 are negligible, not more than $0.5 \%$ of total product compared to $16 \%$ in late Roman Egypt ca. 550, because the Umayyad State is now acquiring the great bulk of the grain surplus. When applied to Antaeopolis, the total tax per household of 6.8 solidi yields the following results: total product for Antaeopolis is the same as it had been ca. 550, but the tax-rate rises from $32.5 \%$ to $50 \%$; net product falls from $42 \%$ to $39.5 \%$, population falls from 18,000 to 16,800 and each labour-unit now works 150 days per year. The burden on the agrarian economy is heavier than in the model for Antaeopolis ca. $55^{\circ}$ but the economy remains viable.

\section{Model IV: Nessana ca. 685-69o (Theoretical Maximum Exploitation, Appendix E)}

The last model represents Nessana in the 68os. The Nessana papyri show three main pieces of fiscal evidence for this decade. First, various amounts are recorded as payments for epikephalion (equivalent to diagraphon, the tax paid by adult males) and demōsia (the tax paid by landowners). Papyrus 59

19 Simonsen, Studies in the genesis 90-92, 116, 124; Dennett, Conversion 86; Bell, Adminstration $278-286$. 
records that for one year a person paid twelve solidi, six as epikephaliōn and six as demōsia. Papyrus 55 records that a churchman paid another person's annual demōsia of 4.33 solidi. Papyrus 58 records that the priest Sergius paid tax (probably demōsia for a single year) of 37.5 solidi for land assigned to him by the Arab governor. ${ }^{20}$

The fragmentary papyrus 77 gives twenty-two other payments from individuals, varying from 0.5 to 23 solidi and averaging 7.5 solidi each. The payments were all classified as epikephalion and demōsia. It is impossible to specify them individually, but the larger payments $(23,21,20,20$ and 15 solidi) probably represent epikephaliōn or demōsia payments in arrears for one year. It seems unlikely that arrears for several consecutive years would be recorded as a lump sum. The smaller amounts $(0.5,1,1.5,3.75$ solidi) might also represent payments in arrears for one year. More likely, though, they represent instalments of arrears payable three or four times a year. ${ }^{21}$

The second piece of evidence is papyrus no. 69, which gives all grain and oil payments paid by Nessana during the period September 680-September 681 . These payments are called rouzikon (rizq), and they total 87 solidi. The last, crucial piece of evidence is papyrus no. 76 , dated 689 , which gives a list of adult males liable for the epikephalion tax. The list is alphabetical and records only names, not amounts. The papyrus is incomplete, but its original size can be known and the number of missing names estimated. The list should have held about 180 names in total. ${ }^{22}$

Each piece of evidence is significant. First, the rouzikon of 87 solidi per year for Nessana as a whole is too small to have been a regular tax. Since the Nessana papyri give no other record of payments in kind, it seems likely that the Umayyad authorities in Palestine during the 680s no longer levied tax in gold and grain on the Roman model. They were now levying the tax in gold, divided about equally between demōsia and epikephaliōn. The rouzikon then was only a small extra payment made to local Arab soldiers who, as shown by papyrus 92, were already receiving annual salaries of about ten solidi each. ${ }^{23}$ This conclusion would invalidate the theory, based in part on a misinterpretation of the rouzikon demand-notes from Nessana, which argues that the Arab administration in the conquered territories operated at first on a decentralised and ad hoc basis and only became properly organised towards

\footnotetext{
20 Kraemer, Excavations 153-155, 168-171, 172-174.

21 Kraemer, Excavations 222-225.

22 Kraemer, Excavations 199-201.

23 Kraemer, Excavations 290-296.
} 
the end of the seventh century. This view corresponds well, however, with the situation in Egypt. ${ }^{24}$

Secondly, the amounts paid in demōsia and epikephaliōn seem much higher on average than the equivalent amounts paid at Aphrodito a little later. This is certainly true for amounts known to have been single annual payments (4.3 solidi, 6 solidi, 37.5 solidi). It is probably also true for the 22 indeterminate payments given in papyrus 77 , which average 7.5 solidi each. In contrast, the average demōsia payment at Aphrodito in 705 was only 2.3 solidi and the average diagraphon payment 2.4 solidi. It is theoretically possible that the recorded payments at Nessana represent payments by richer tax-payers only, but it seems more reasonable to suppose that the taxes paid by household heads were higher than at Aphrodito.

Finally, the population of Nessana in the 68os seems to have been much smaller than it was in the mid-sixth century. Considering that poll-tax was levied on all adult males from 14-65 years, the total of 180 persons liable to poll-tax listed in papyrus 76 would indicate a total population of only about 800 in the 680 s compared to about 2,60o in ca. 550 as deduced in Model II. ${ }^{25}$

The papyri evidence for Nessana in the 68 os thus points to a combination of high taxes per head and low overall population. As explained above, this combination is typical of the grain-based economy as it nears the point of maximum exploitation. Therefore, using the baseline figures in Model II, it may be revealing to describe Nessana's economy at its theoretical -point of maximum exploitation and then compare the results with the papyri evidence for the 68os. The same assumption is made here as for Antaeopolis in 705 (Model III), that outgoing rent payments to large private landlords are negligible, not more than $0.5 \%$ of total product because the Umayyad State has monopolised the grain surplus.

Under conditions of maximum exploitation at Nessana, total product would remain as before at 248,000 grain-units, equivalent to 8,270 Umayyad solidi, and the required number of man-days remains at 93,000. The tax-rate under these conditions must be $74 \%$, so that after further deductions of $12.5 \%$ for seed and $0.5 \%$ for rent, net product is only $13 \%$, equivalent to just over 30,000 grain-units. This amount would support a population of 800 , and 350 days of

24 Petra Sijpesteijn argued that a similar centrally organised financial administration of the Arab administration was already in place in Egypt directly following the conquest (The Arab conquest). See also Clive Foss's discussion of the Greek papyri from Edfu which show a well-organised Arab administration at the time of Mu'āwiya (Foss, Egypt under Mu'āwiya. Part I and II).

$25 \quad$ Kraemer, Excavations 31. 
labour, about the maximum possible number, would be required annually per cultivator. The total tax per household is 30.5 Umayyad solidi.

This model of Nessana's economy under theoretical conditions of maximum exploitation corresponds with the available papyri evidence, and the evidence can be interpreted by the model. In particular, there is a strong correspondence between a total population of 800 under theoretical conditions and the total of 180 adult male tax-payers found in papyrus 76 . There is also a weaker yet still significant correspondence between the high household tax paid under theoretical conditions and the evidence of taxes actually paid at Nessana during the 68 os. The theoretical total tax of 30.5 solidi per household divided equally between demōsia and epikephaliōn would give 15 solidi for each tax. Only four annual tax payments at Nessana are specified as either demōsia or epikephalion, and they are recorded as 4.3, 6, 6 and 37.5 solidi. The average of these four payments is close to 15 solidi, but the payment of 37.5 solidi was levied on land transferred to the priest Sergius from an Arab clan and could therefore have been an unusually large payment. ${ }^{26}$ However, the twenty-two payments in papyrus 77 average 7.5 solidi each. If these were mostly instalments on arrears (and the document probably is a register of tax arrears), then the twenty-two payments may offer evidence for annual demōsia and epikephaliōn taxes of 15 solidi each per household. Indeed, taxes of that size would likely have been paid in instalments rather than all at once. The indeterminate nature of these twenty-two payments makes them inconclusive as evidence. But at any rate, it can be stated firmly that the average of all payments recorded at Nessana in the 68 os is 8.4 solidi, which is about two and a half times as high as the average tax paid at Aphrodito in 705. To recall, the recorded average taxes at Aphrodito were 2.3 solidi demōsia, 2.4 solidi diagraphon, and 2.1 solidi foodstuffs, making a total tax of 6.8 solidi per household. But for purposes of comparison, the 2.1 solidi for foodstuffs paid at Aphrodito should be allocated equally between the two money taxes in order to reflect the absence of important taxes in foodstuffs at Nessana. Thus each annual money tax at Aphrodito came to 3.4 solidi on average, compared with an average recorded payment at Nessana of 8.4 solidi.

The picture outlined by the statistics and models is coloured by two other fiscal items from the Nessana papyri. Papyrus 75, the letter organizing a tax protest, is without counterpart in the body of papyri from the Late Roman and early Islamic periods. It is undated but certainly contemporary with the other fiscal papers from the 68os. The writer is from an unknown town in the district. He 
has addressed his letter to someone in another unknown town, who forwarded it finally to Nessana:

We wish to inform your Noble Magnificence, Beloved of God, that we have received a letter from His Magnificence, Lord Samuel. He personally invites both you and us at the same time to appeal to our most esteemed Governor to grant us relief, for they have caused us both serious distress and we cannot bear the burden of such taxation (panu gar ebaresan hèmas kai humas kai ou dunōmetha bastaze tō toiouto phortion). Note therefore, that tomorrow, Monday, we shall be in Gaza. There are twenty of us. Will you too please come immediately so that we may all be of one mind and one accord? After you have read the present letter, send it to Nessana. We have written to Sobata. Good luck and good health to you! ${ }^{27}$

According to the analysis of the editor, C.J. Kraemer, at least four towns are involved in the protest - the writer's and the recipient's towns, plus Sobata and Nessana. The twenty people mentioned do not come from any of the last three towns, but probably only from the writer's town. Samuel himself, the originator of the protest, probably raised more people from elsewhere. Therefore, the protest could have easily have involved up to a hundred people. Kraemer implicitly admits but does not emphasise the "serious distress" revealed by this letter. In fact, he interprets the document

not merely as evidence of burdensome taxation but of the machinery which had been devised to protect the tax-payer [...] This delegation knows the force of concerted protest, and the availability of the symboulos (the Arab governor) for an interview has a parallel from Egypt: in a letter written in 710 (P.Lond. IV 1356), the governor Qurra ibn Sharik reprimands his subordinate Basileios for not paying sufficient attention to the complaints of his people. ${ }^{28}$

Yet Papyrus 75 does not give the impression that the Arab governor is normally available to hear complaints from tax-payers. Nor, supposing that he were available on this occasion, does Papyrus 75 suggest that he is likely to

\footnotetext{
27 Kraemer, Excavations 212-214. See also the discussion of this text and its context of redress of public complaints in El-Abbadi's paper in this volume.

28 Kraemer, Excavations 212-213.
} 
reduce the taxes significantly. The document indicates that the protesters are taking an unusual course of action, one that may have had no precedent and whose outcome could only be guessed. The only clear conclusion to be drawn from Papyrus 75 is that the tax was so high as to prompt a widespread protest by representatives of the conquered Christian population of southern Palestine. This evidence and the statistics in Model IV corroborate each other, reinforcing the impression that the tax levied in Palestine in the 680s was very high. In that case, it would be reasonable to interpret the phrase 'we cannot bear the burden of such taxation' as a plain statement that the local agrarian economy had reached the point of maximum exploitation theorised in Model IV.

The last piece of fiscal evidence from the Nessana papyri is a letter in Arabic on the verso of Papyrus 77, the register of twenty-two indeterminate payments datable 685-69o. The letter must therefore have been written in the same period or soon afterwards. Kraemer did not publish this letter along with the other eighty-four documents that he edited. He only refers to it briefly in his commentary to Papyrus 56, dated January 687, a curious Arabic-Greek document worthy of mention in itself. ${ }^{29}$ The fragmentary Arabic part is witnessed by four Arabs, and the Greek section, full of errors, is written by the archdeacon Father George and witnessed by his superior, the priest Sergius. The document states that an Arab named al-Aswad ibn 'Adī has received fifty solidi from Father Cyrin in exchange for releasing Father Cyrin's son, and that from this amount al-Aswad returns twenty solidi to Father Cyrin "for the sake of God" (șadaqa 'alayhi bi-ishrīn dinār/nomismata eikosi echarisato alasouad to abba kurin). Al-Aswad also promises that both father and son can go where they want, al-Aswad has no authority over the father, and neither he nor his heirs have any claim over the son. It seems that the father is in effect paying thirty dīnārs to redeem his son from a period of forced labour or outright slavery, al-Aswad having returned part of the original redemption as an act of liberality. Yet Kraemer relies on the interpretation of previous scholars, that al-Aswad had originally advanced fifty dīnārs to Father Cyrin for the indentured employment of his son. The indenture is now over and al-Aswad receives the money, but he gives back twenty dīnārs to Father Cyrin in lieu of salary. But if this is the correct interpretation, the wording of the document is very misleading.

In any case, the first of the four Arab witnesses to this document is Yazīd ibn Fāiid, and here Kraemer notes that this name also appears in the Arabic 
verso of Papyrus 77: "There Yazīd ibn Fā'id receives a letter from a superior official, Nabr ibn Qays, rebuking him in very strong terms for injustice and oppression to the people of Nastān [Nessana], for he [Nabr ibn Qays] remarks, 'the people of Nastān are under the protection of God." Kraemer thinks that Yazīd was probably the $q \bar{a} d \bar{\imath}$ or judge of Nastan because "dealing with contracts

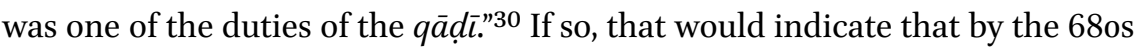
Nessana had a significant Arab-Muslim population. But Nabr ibn Qays' remark that "the people of Nastān are under the protection of God" (dhimmat allāh) suggests instead that Nessana remained an entirely Christian town in the late 68os. In that case, al-Aswad and other Arabs mentioned in Papyrus $5^{6}$ were not inhabitants of Nessana itself but probably belonged to tribal groups now settling in the vicinity, the same who supplied the soldiers listed in Papyrus 92. The $q \bar{a} d \bar{\imath}$ 's authority was restricted to the Muslim community, so if Yazìd ibn Fầid was oppressing the Christian population of Nessana, it is more likely that his function in relation to them was fiscal. He was probably the fiscal administrator ('âmil) of the local district (iqlimm) of Elusa.

But according to Kraemer's brief summary, the main point of this unpublished letter was Yazid's fiscal oppression of Nessana, which establishes a clear connection with the contemporary Papyrus 75 , the tax protest letter. We thus have two pieces of documentary evidence indicating that Nessana's agrarian economy at that time was heavily strained. Indeed, it seems that the economy was now exploited beyond its limit because the town of Nessana likely ceased to exist soon after 700. Apart from the papyri, other early Islamic evidence from the town is limited to a little pottery and glass classified as Umayyad and ten undated bronze coins. ${ }^{31}$ The pottery and glass probably predate 700 , for the glazed ceramic wares classified as Abbasid became widespread in the later Umayyad decades after 700. On the other hand, the coins are of the aniconic type not minted before 696-697. But coins are easily deposited in transit, and without accompanying evidence these examples do not confirm that Nessana was permanently occupied after 70o. Much more significant is the abrupt termination of the papyrological evidence. The list of poll-tax payers, written in 689 , marks the end of the extant tradition going back to 505 .

Papyri 55, 58, 59, 76 and 77 altogether corroborate the maximum-exploitation model theorised in Model IV. And Papyrus 75, the tax protest letter, shows that in the 68os fiscal oppression was common to the whole province (küra) of

3o Kraemer, Excavations 159. This text is being prepared for publication by Robert Hoyland.

$31 \quad$ Kraemer, Excavations 30. 
southern Palestine governed by the Arab symboulos at Gaza. On the other hand, the verso of Papyrus 77 shows Nabr ibn Qays, a higher official and probably the symboulos himself, reprimanding a subordinate Arab official for oppressing the people of Nessana. The question arises whether the fiscal oppression was mainly caused by the private depredations of local district officials such as Yazīd ibn Fāiid, or whether it derived mainly from the general fiscal policy administered by Gaza and ultimately decided by the central government in Damascus. The latter alternative seems more likely, for the wording of the tax protest letter gives the impression that the central authorities are directly responsible for the heavy taxation. It gives no hint of corrupt local tax-officials. Also, it is notable that Arab-Muslim tax-collectors are attested only in the entagia or demand-notes for foodstuffs, which raised small sums by comparison with the two main taxes. A typical example of an entagion from Nessana reads:

Al-Ḥārith ibn 'Ad (the local district official or 'ämil based at Elusa) to the people of Nestana, district (iqlìm) of Elusa, province (küra) of Gaza: pay quickly to 'Adī ibn Khālid of the Banī Sa'd ibn Mālik for the five months Dhū al-Qa'da, Muḥarram, Șafar and the two Rabī‘ss, seventy modii of wheat and seventy sextarii of oil. ${ }^{32}$

But the demōsia and epikephaliōn amounts recorded in Papyri 55 and 59 were paid to John and Victor, tax-collectors who had come to Nessana from Gaza, and the documents were dated by the calendar of Gaza. The evidence indicates that the main taxes were set and raised by the central authorities using their own Christian officials.

It remains to consider what factors lay behind an official policy to impose taxation so high as to threaten the Palestinian agrarian economy. Such a policy was not generalised in the Umayyad State, for the case of Aphrodito in 705 (Model III) indicates a high yet sustainable level of taxation. Generalisation of the policy evidenced at Nessana would have rapidly destroyed the agrarian economy upon which the State rested. Yet this destruction is what seems to have happened in large areas of Palestine and Syria during the late seventh and eighth centuries, according to the evidence of site occupation in four areas covered by archaeological survey:33

$32 \quad$ Kraemer, Excavations 183.

33 Compiled from reports in MacAdam, Settlements 80-82; Dauphin, Jewish 132. 
Survey area and date

$\begin{array}{ll}\text { Number of sites } \\ \text { Late } & \text { Early } \\ \text { Roman } & \text { Islamic }\end{array}$

\begin{tabular}{lll} 
'Araq al-Amir (near Amman, 1980s) & 83 & 30 (all Umayyad) \\
Tell Hisbān (near Amman, 1968-1976) & 133 & 33 (29 Umayyad, 4 Abbasid) \\
Tell al-'Umayrī (Madaba Plains, 1987) & 21 & 1 (Umayyad) \\
Golan (1972) & 90 & 13 (undistinguished) \\
\hline
\end{tabular}

In these four survey areas, the extent of site abandonment in the Umayyad period ranges from $70-95 \%$. Other surveyed areas include the Limestone Plateau, the plateaux east and north-east of Hama, the southern Hawran, the Negev and the 'Araba and Wādī al-Hasā valleys in southern Jordan. These areas likewise show a large drop in the number of sites occupied during the early Islamic period. ${ }^{34}$

The difficulty of dating ceramic styles to within a period of less than fifty years means that, relying on material evidence alone, we can be certain only that the agrarian economy in Palestine and Syria was substantially reduced during the period $640-800$. Yet it seems likely that this decline was marked by three important stages: the Arab conquest, the late seventh and early eighth centuries, and the collapse of Umayyad rule in $75^{\circ}$.

The second stage is of particular interest in the case of Nessana. Several possible factors are connected with the super-taxation of the agrarian economy in Palestine and Syria from the end of Mu'āwiya's caliphate in 680 if not earlier. Except during the period of civil war from 684-692, the early Umayyad State was undertaking a relentless attack against the Byzantine Empire. The campaigns included especially the naval and military expeditions against Constantinople in $654,674-678$ and $716-717$, but also the annual invasions of Asia

34 Finkelstein and Perevolotsky, Processes of sedentarization 8o, for the northern Negev (there is separate evidence of new settlements, probably of Arab nomads, in the southern Negev during the Umayyad period: Haiman, Agriculture and nomad-state 30-46; Avni, Early mosques 91-93.) See Schick, The settlement 135 for the surveys in southern Jordan, and Foss, Syria in transition 233 for surveys in the regions east and north-east of Hama, where 'no identified remains or inscriptions of either the Umayyad or Abbasid periods have been reported ...' For a slightly different view on the pattern of flourishing and decline in this period in this area, see Walmsley, The village ascendant and Walmsley, Early Islamic Syria. 
Minor, the conquest of Byzantine North Africa during the 69os and the conquest of most of Spain in the years 711-718. All these efforts were undertaken largely by Syrian Arab forces, and their expense was borne disproportionately by the conquered population of Syria and Palestine, the only such group that was directly administered by the Umayyad State. Domestic factors also tended towards heavy taxation during this period in Syria and Palestine. From his accession in 685 to 692 , the caliph 'Abd al-Malik (r. 685-705) fought the second Arab civil war against opponents based in Iraq and Arabia. He and his successor al-Walīd (r. 705-715) supervised a building program that included the Dome of the Rock in Jerusalem, the Umayyad Mosque in Damascus, roads and post-houses in Palestine, and a dozen or so palace complexes in Transjordan. Finally, Christians in western Syria were involved in a long revolt against the Umayyad State that began with the destruction of the Arab expedition against Constantinople in 678 and lasted until the mid-69os. Known as the Mardaïte revolt from the account given by Theophanes, this uprising permitted the establishment of a short-lived Christian state in the coastal mountain ranges of Amanus and Lebanon. The revolt was supported by the Byzantine Empire, which apparently profited from it by the temporary recapture of Antioch in 686.

The fiscal evidence from Nessana during the 68os thus reflects a time of great disturbance in Palestine and Syria, a time of civil war among the Arab conquerors and revolt among the conquered population. In the midst of this confusion, in 686-687, Theophanes records, 'there was a famine in Syria and many men migrated to the Roman country'. ${ }^{35}$ All this provides the background for an unusually heavy tax regime that submerged the agrarian economy it exploited. To repeat, this tax regime was not generalised in the early Islamic State, nor could it be if the State were to survive. Nevertheless, periods of fiscal oppression accompanied by revolts and social disturbances recur in different regions during the course of early Islamic history. Well-recorded examples come from Egypt during the last three decades of Umayyad rule and especially from Upper Mesopotamia during the period $75^{0}-775$, a time of troubles described in eyewitness detail in a long passage of the Zuqnin Chronicle. ${ }^{36}$ Claude Cahen's standard discussion of this passage in a 1950 article is generally misleading, focusing much more on the element of urban-rural and class conflict than on the more fundamental factor of fiscal oppression. ${ }^{37}$ It would be a useful task to

\footnotetext{
35 Theophanes, The chronicle 507.

36 Chronique de Denys de Tell-Mahré.

37 Cahen, Fiscalité.
} 
combine the documentary fiscal evidence from Nessana with the literary detail from the Zuqnin Chronicle in order to gain insight into this recurrent aspect of early Islamic history.

\section{Appendices}

\section{A Constant Factors Used for Economic Models}

Unit of grain is the Roman modius (9 litres), holding 6.55 kilograms of grain

Average consumption per person is 40 grain-units per year $(260$ kilograms grain-equivalent)

33 grain-units equals one Roman solidus at the standard fiscal rate 30 grain-units equals one Umayyad solidus at the standard fiscal rate

On ordinary grain-land, 20 grain-units sown per hectare yield sevenfold or eightfold ( 150 units) every other year.

On irrigated Egyptian land, 12 units sown per hectare yield tenfold (120 units) every year.

Cultivation of one hectare requires 60 man-days.

One adult male cultivates 6 hectares at full capacity ( 360 days per year).

Ordinary grain-land and irrigated land are assumed to require a similar amount of labour.

Grain cultivation is normally undertaken by adult males only.

One adult male equals one labour-unit.

One adult female equals one half labour-unit.

One child equals one-quarter labour-unit.

Cultivating labour-units (adult males only) equal one-third of total population.

Model I: Antaeopolis ca. 550

Papyri Evidence

Cultivated area Tax 14,00o hectares (ha) 16,500 solidi of which $62 \%$ in gold, $38 \%$ in grain 
Deductions

Total product in grain $1,700,000$ units

$(14,000 \times 120)$

Total product in gold 51,000 solidi

$(1,700,000 \div 33)$

Man-days required

840,000

$(14,000 \times 60)$

Tax-rate

$32.5 \%$

$([16,500 \div 51,000] \times 100)$

Assuming

Net product

$7 \cdot 5 \%$ total product in rent, then

Net product in grain $50 \%$

(100\%-32.5\%-10\%-7.5\%)

Total population

850,000 units

$(1,700,000 \times 50 \%)$

Labour-units

21,000

$([1,700,000 \times 50 \%] \div 40)$

Days per labour-unit $\quad 120$

$(21,000 \times 33 \%)$

Tax per household

7,000

$(840,000 \div 7000)$

3.1 solidi

$(16,500 \div[21,000 \div 4])$

Check

Total population of

Egypt

Assuming

Net product

Total population

Labour-units

Days per labour-unit

Tax per household
4.5 million

$(21,000 \times 0.5 \%+300,000$

Alexandria)

$16 \%$ total product in rent, then

Net product in grain

$42 \%$

714,000 units

18,000

6,000

140

3.7 solidi

$(100 \%-32.5 \%-10 \%-16 \%)$

$(1,700,000 \times 42 \%)$

$([1,700,000 \times 42 \%] \div 40)$

$(18,000 \times 33 \%)$

$(840,000 \div 6,000)$

$(16,500 \div[18,000 \div 4])$

Check

Total population of $\quad 3.9$ million

Egypt
$(18,000 \times 0.5 \%+300,000$

Alexandria)

\section{Model II: Nessana ca. $55^{\circ}$}

Papyri Evidence

Tax in gold $\quad 1,400$ solidi

Grain-yield Sevenfold to eightfold

Assuming Tax at the proportion $62 \%$ gold, $38 \%$ grain

Rent at $7 \cdot 5 \%$ total product

Net product at $50 \%$ total product, then

Total tax

2,26o solidi

$(1,400+[[1,400 \div 62] \times 38])$ 


$\begin{array}{lll}\text { Tax-rate } & 30 \% & (100-50-12.5 \text { seed-7.5 rent }) \\ \text { Total product in gold } & 7,530 \text { solidi } & (2,260+[[2,260 \div 30] \times 70]) \\ \text { Total product in grain } & 248,000 \text { units } & (7,530 \times 33) \\ \text { Cultivated area } & 1,650 \text { ha per year } & (248,000 \div 150) \\ & 3,310 \text { ha total } & (1,650 \times 2) \\ \text { Man-days required } & 100,000 & (1,650 \times 60) \\ \text { Net product in grain } & 124,000 \text { units } & (248,000 \times 50 \%) \\ \text { Total population } & 3,100 & (124,000 \div 40) \\ \text { Labour-units } & 1,030 & (3,100 \times 33 \%) \\ \text { Days per labour-unit } & 100 & (100,000 \div 1,030) \\ \text { Tax per household } & 2.9 \text { solidi } & (2,260 \div[3,100 \div 4])\end{array}$

Check

Population density $\quad 260$ persons/ha $\quad(3,100 \div 12$ ha built-up area $)$

Assuming $\quad 16 \%$ total product in rent and $42 \%$ net product, then other factors are unchanged except

Net product in units

104,000 units

$(248,000 \times 42 \%)$

Total population

2,600

$(104,000 \div 40)$

Labour-units

870

$(2,600 \times 33 \%)$

Days per labour unit $\quad 115$

$(100,000 \div 870)$

Tax per household

3.5 solidi

$(2,260 \div[2,600 \div 4])$

Check

Population density $\quad 190$ persons/ha $\quad(2,260 \div 12$ ha built-up area $)$

D Model III: Antaeopolis ca. 700

Papyri Evidence

(Aphrodito P.Lond. IV 1420, village of Pente Pediades, 95 adult males in the year 705)

Average diagraphon

Average demōsia

Average foodstuffs

Total

Assuming

Tax per household
2.4 Umayyad solidi

2.3 Umayyad solidi

2.1 Umayyad solidi equivalent

6.8 Umayyad solidi

$0.5 \%$ rent, then

6.8 Umayyad solidi $\quad(2.4+2.3+2.1)$ 
Total product in grain

Total product in gold

Cultivated area

Man-days required

Deduction for seed

Tax-rate

Total tax in gold

Net product

Net product in grain

Total population

Labour-units

Days per labour-units
1,700,000 units

56,670 Umayyad solidi $\quad(1,700,000 \div 30)$ 14,000 ha

840,000

$10 \%$

$50 \%$

28,335 Umayyad solidi

$39.5 \%$

16,800

5,600

150

(as Model I)

(as Model I)

(as Model I)

(as Model I)

$(56,670 \times 50 \%)$

$(100-50-10-0.5)$

$(672,000 \div 40)$

$(16,800 \times 33 \%)$
672,000 units

(trial and error)

$(1,700,000 \times 39.5 \%)$

$(840,000 \div 5,600)$

Check

Tax per household $\quad 6.75$ Umayyad solidi $\quad(28,335 \div[16,800 \div 4])$

$\mathbf{E}$

Model IV: Nessana ca. 685-69o (Theoretical Maximum Exploitation)

Papyri Evidence

Annual payment of epikephaliōn

6 solidi

Annual payments of demōsia

4.3 solidi, 6 solidi, 37.5 solidi

22 indeterminate payments

$0.5^{-23}$ solidi, averaging 7.5 solidi

List of grain and oil payments for one year Total 87 solidi

List of poll-tax payers

Total about 180 persons

Assuming

Total product in grain

Total product in gold

Cultivated area

Man-days required

Tax-rate

Total tax in grain

Total tax in gold

Net product

Net product in grain

Total population

Labour-units

Days per labour-unit

Tax per household
$0.5 \%$ rent, then

248,000 units

8,270 Umayyad solidi $\quad(248,000 \div 30)$

3,100 ha

93,000

$74 \%$

183,500 units

6120 Umayyad solidi

$13 \%$

32,250 units

800

265

350

30.5 Umayyad solidi

(as Model II)
$(248,000 \div 30)$
$($ as Model II)
(as Model II)
(trial and error)
$(248,000 \times 74 \%)$
$(183,500 \div 30)$
$(100-74-12.5-0.5)$
$(248,000 \times 13 \%)$
$(32,250 \div 40)$
$(800 \times 33 \%)$
$(93,000 \div 265)$
$([6,120 \div[800 \div 4])$




\section{Bibliography}

\section{Primary Sources}

Dionysius of Tell Maḥrē (d. 845), Chronique de Denys de Tell-Mahré, ed. and trans. J.-B. Chabot, Paris 1895 .

Theophanes (d. 817 or 818), The Chronicle of Theophanes Confessor: Byzantine and Near-Eastern history, AD 284-813, eds. C. Mango and R. Scott, Oxford 1997.

Vico, G., The new science of Giambattista Vico, Unabridged translation of the third edition (1744) with the addition of 'Practic of the new science', eds. and trans. T.G. Bergin and M.H. Fisch, Ithaca and London 1984.

\section{Secondary Sources}

Allen, P., The Justinian Plague, in Byzantion 49 (1979), 5-20.

Avni, G., Early mosques in the Negev highlands: New archaeological evidence, in BASOR 294 (1990), 83-100.

Banaji, J., Agrarian change in late antiquity: gold, labour, and aristocratic dominance, 2nd ed., Oxford 2007.

. Aristocracies, peasantries and the framing of the early middle ages, in Journal of Agrarian Change 9 (2009), 59-91.

Bell, H.I., The administration of Egypt under the Umayyad Khalifs, in Byzantinische Zeitschrift 28 (1928), 278-286.

Cahen, C.A., Fiscalité, propriété, antagonismes sociaux en haute-Mésopotamie au temps des premiers 'abbâssides d'apres Denys de Tell Mahré, in Arabica 1 (1954), $136-15^{2}$.

Dauphin, C.A., Jewish and Christian communities in the Roman and Byzantine Gaulanitis: A study of evidence from archaeological surveys, in Palestine exploration quarterly 114 (1982), 129-142.

Dennett, D., Conversion and the poll tax in early Islam, Cambridge, Mass. $195^{\circ}$.

Finkelstein, I. and A. Perevolotsky, Processes of sedentarization and nomadization in the history of Sinai and the Negev, in BASOR 279 (1990), 67-81.

Foss, C., Syria intTransition, A.D. 550-750: An archaeological approach, in Dumbarton Oaks papers 51 (1997), 189-269.

- Egypt under Mu'āwiya. Part I: Flavius Papas and Upper Egypt, in BASOR 72 (2009), 1-24.

—. Egypt under Mu'āwiya. Part II: Middle Egypt, Fusțāṭ and Alexandria, in BASOR 72 (2009), 259-278.

Frantz-Murphy, G., The economics of state formation in early Islamic Egypt, in From al-Andalus to Khurasan. Documents from the medieval Muslim world, eds. P.M. Sijpesteijn et al., Leiden 2007, 101-114.

Haiman, M., Agriculture and nomad-state relations in the Negev desert in the Byzantine and early Islamic periods, in BASOR 297 (1995), 29-53. 
Hopkins, K., Taxes and trade in the Roman empire (B.C. 200-A.D. 400), in Journal of Roman studies 70 (1980), 101-125.

Horden, P., Mediterranean plague in the age of Justinian, in M. Maas (ed.), The Cambridge companion to the age ofJustinian, Cambridge 2006, 134-160.

Jones, A., Census records of the later Roman empire, in Journal of Roman studies 43 (1953), 49-64.

. The decline of the ancient world, London, 1966.

King, G.R., and A. Cameron (eds.), The Byzantine and early Islamic Near East, II., Princeton 1994 .

Kraemer, C.J. Jr., Excavations at Nessana: Non-literary papyri, Princeton 1957.

MacAdam, H.I., Settlements and settlement patterns in northern and central Transjordania, ca. 550-ca. 750, in A. Cameron and G.R. King (eds.), The Byzantine and early Islamic Near East, II., Princeton 1994, 49-93.

Ruffini, G., Social networks in Byzantine Egypt, Cambridge 2008.

Sarris, P., The Justianic plague: Origins and effects, in Continuity and change 17 (2002), 169-182.

- Rehabilitating the great estate: Aristocratic property and economic growth in the late antique East, in W. Bowden, L. Lavan and C.A. Machado (eds.), Late antique archaeology, vol. II: Recent research on the late antique countryside, Leiden 2004, 55-71.

- Economy and society in the age ofJustinian, Cambridge 2006.

_. Procopius - The secret history —Translated by G.A. Williamson and Peter Sarris with introduction and notes by Peter Sarris, London 2007.

Schick, R., The settlement pattern of southern Jordan, in A. Cameron and G.R. King (eds.), The Byzantine and early Islamic Near East, Princeton 1994, 133-154.

Sijpesteijn, P.M., The Arab conquest of Egypt and the beginning of Muslim rule, in R.S. Bagnall (ed.), Egypt in the Byzantine world 300-70o, Cambridge 2007, 437-459.

_. Landholding patterns in early Islamic Egypt, in Journal of agrarian change 9 (2009), 120-133.

Simonsen, J.B., Studies in the genesis of the caliphal taxation system, Copenhagen 1988.

Walmsley, A., The village ascendant in Byzantine and early Islamic Jordan: Socioeconomic forces and cultural responses, in C. Morrisson and J.-P. Sodini (eds.), Les villages dans l'Empire byzantine, Paris 2005, 511-522.

_. Early Islamic Syria: An archaeological assessment, London 2007.

Zorn, J.R., Estimating the population size of ancient settlements: Methods, problems, solutions and a case study, in Bulletin of the American Schools of Oriental Research 295 (1994), 31-48. 